\title{
山崎貞一元会長を偲んで
}

\section{（元会長）春山 志郎}

山崎貞一元会長が89歳の天寿を全うされ，あの温厚なお顔 にお目にかかれなくなるのは淋しい限りです。

私は，以前から山崎さんを存じ上げたいたのですが，親し くお話させて頂く様になったのは, 昭和 43 年, 山崎さんが本 会副会長になられてからです，当時私は，笛木先生等と編集 理事を務めており，山崎さんから TDKの創陪期のお話など 伺ったものでした，いつも温和な山崎さんが，大手メ一カ一 の磁気テープ事業への参入について，「わが国では，こうして 大手メーカーがベンチャーを苦しめる.」と嘆いておられたの を覚えております。

私は東工大出身ですが，電気化学科の卒業ではないので, 長い間，山崎さんは私を東大か横浜国大の卒業生と思ってい た様です、私を同葖生と認知されたのは, 昭租 54 年山崎さん が本会会長に就任された頃です。当時, 本会は経済的に苦し く, 事務職員の退職積み立てもできず，年末には銀行から借 金，会計年度を繰り上げる話も出ました，見るに見かねた山 崎会長からご寄付を頂き，やっと本会は息を吹き返したもの でした。

当時は，本会の庶務 $\mathrm{OB}$ 会を毎年やっておりましたが，山 崎会長のご厚意で 54 年は佐久 TDK 見学旅行, 55 年は伊豆 今井浜䭒談旅行にご招待頂きました。 今井浜には，早川，小 寺, 松野等の諸先生に武井事務局長が加わり総势 12 名が参
加し, 会長ご厚意のマイクロバスで本会を出発し, TDK 今井 浜荘で留談，翌日は天城越えで修善寺，三島，そして箱根路 を経て帰京と言う日程でした。山崎さんは気配りの人です。 バス旅行中も運転席の側に座ってガイド役を務め，夜の根親 会でも一人一人の樣子に気を配っておられました。

山崎さんは，終生敬愛された加藤与五郎先生が創設された 財団法人加藤科学振興会の理事長を長年勤められ，私もその 栄に浴した加藤記念賞の表彰を行うと共に研究奨励金により 若い研究者の育成に努められました。その表彰・贈呈式では， いつも山崎理事長が加藤先生の思い出を懐かしそうに括話し になるのが印象的でした。

山崎さんは愛校心の強い方でした，東工大の正門脇にある 百年記念館も山崎さんのご協力なくしては建たなかったと思 いますし，またその後も私財をなげうって，東工大の若い研 究者の育成にご尽力頂きました，また，山崎さんは東工大の 同空会である蔵前工業会の会長を務颀，ややもすると沈 滞気味であった同空会の活性化にご尽力されました，当時， 私は蔵前工業会関東支部の役員であり，役員会では，始めて 大先輩と後輩として山崎さんとお付き合いさせて頂きました。 わが国の技術開発の歴史と共に生きた方であり，本会にとっ ても東工大にとっても大切な人を失った思いが致します。

以上，昔を偲んでお別れの言葉と致します。

\section{山崎貞一元会長を偲んで}

\section{（前会長）岸 富也}

山崎貞一さんが昨年 11 月 20 日卒然として幽明境を異にさ れた，再びその温容に接することができない，寂胗の感に耐 えない。

山崎さんは，昭和 54 年衆望を担って第 26 代会長に就任さ れた，当時，本会は多年にわたり続いた苦しい財政環境にあ り，一時的にせ上会員有志から前納会費を受ける程の状態に あった．就任早々，山崎さんは「こんなことで大学の先生に ご苦労をかけては‥」と直ちに赤字補填のための援助を申し 出られた：その意気に力を得て会長を中心に，役員・事務局． 員一丸となって財政の健全化に悪命の努力を重ねた。これに よって,山崎さんからのその後の寄付金を合わせ，その全額 を山崎基金として積み立てることができるまでに財政を再建 することができ，さらにその勢いは，その後本会の創立 50 年 を節目として現在に至る会の新なな発展への出発点となった。 山崎さんは, 束京工業大学において故加藤与五郎, 武井 武 両教授の教之を受けられた。昨年 11 月 4 日の加藤科学振與会 の加藤記念賞の授与式の席上，当時を回顧しながら次のよう に述べられた、加藤先生は学生の就職の世話をしない。した がってその点で学生の評判が悪い。これに対多る先生の持論 はこうである。卒業してただ就職するのは最も愚かである。
大学で研究活動を行い，実用化出来る研究成果を仕事の種と して，これを持って実業界に入るべきである，私は，先生に よろしく㹉いします，と言った.」山崎さんは加藤，武井両 教授の下で，両氏の発明になるフェライトの研究に情熱を傾 け，その工業化に生涯を照けられた。今日我が国のフェラ イト工業の隆盛は企業家としての山崎さんの貢献なしに語る ことは出来ない.

我が国で誕生したフェライト磁心の工業化の道程は，特に 戦中戦後にまたがるその創設期に扔いては，苦難の連続であ ったと想像される。しかし，その苦難を一身に背負った山崎 さんは，自らの苦労を語ることは極めて僅く，常に師の「創 造，発明」の精神の「伝道者」であった。

さらに山崎さんは「偉大なdonator」であり，寄付者がそ の志と人德によってはしめてその行為を活かすことが出来る ことを身をもって示された。そして師の志を具現すべく，母 校に，また広く電気化学および電子材料に関連する分野の諸 団体に多くの私財を投じられ。その生前を顧みるとき，こ れは山崎さんの本懐とするところであったであろうと推察さ れる。

心からご冥福をお祈り申し上げる。 